\title{
The Influence of High Temperature Loading on the Structure of Fine Al Powder Compacts
}

Ernest Gondár, Pavol Sejč, Alexander Schrek

Faculty of Mechanical Engineering, Slovak University of Technology in Bratislava. Pionierska 15, 83102 Bratislava. Slovak Republic. E-mail: ernest.gondar@stuba.sk

\begin{abstract}
Aluminum specimens for pilot resistance testing at higher temperature and mechanical loading were prepared by means of powder metallurgy. The aluminum powders with nanooxide surface layers were prepared. The tests were performed at $300^{\circ} \mathrm{C}$ and applied stress of $100,125,150,175 \mathrm{MPa}$ and at temperatures $350^{\circ} \mathrm{C}$ and $400^{\circ} \mathrm{C}$ and stress of $100 \mathrm{MPa}$. Aluminum specimens tested at $300^{\circ} \mathrm{C}$ and stresses of 100 and $125 \mathrm{MPa}$ were characterized by very high resistance. Similar resistance was exhibited by specimens tested at $350^{\circ} \mathrm{C}$ and $100 \mathrm{MPa}$. The rupture of specimens tested at $350^{\circ} \mathrm{C}$ at 150 and $175 \mathrm{MPa}$ was initiated mainly from surface defects. By aluminum tests at temperatures below $400^{\circ} \mathrm{C}$, compact oxide layer was not disturbed. Oxide layer fragmentation at $400^{\circ} \mathrm{C}$ resulted in lower resistance of aluminum specimens. The resistance increase was accompanied by higher portion of ductile fracture with dimpled morphology. Large angle grains size was not changed. Higher temperatures and stresses cause dislocation netting on grain boundaries and initiate subgrains formation.
\end{abstract}

Keywords: aluminum powder, nanooxide layer, thermal resistance, dislocation netting

\section{Acknowledgements}

The contribution was prepared under the support of VEGA project - 1/0234/11.

\section{References}

[1] MICHNA, Š. et al. (2005). Encyklopedie hliníku, Adin - Prešov.

[2] VODĚrOVÁ, M., NOVÁK, P., VOJTĚCH, D. (2013). Compacting of Aluminium Alloys Prepared by Melt Spinning Method. In: Manufactoring Technology, Vol. 13, No. 4, p. 575-580.

[3] PANDEY, A. B., MISHRA, R. S., PARADKAR, A. G., MAHAJAN, Y. R. (1997). Steady state creep behaviour of an $\mathrm{Al}-\mathrm{Al}_{2} \mathrm{O}_{3}$ Alloy, In: Acta mater. Vol. 45, No. 3, p. 1297.

[4] BALOG, M. (2006). Ultra-fine grained Al profiles with high temperature stability, Dissertation theses, Bratislava, 2006.

[5] NAGY, J., SIMANČÍK, F., JERZ, J., BALOG, M., IŽDINSKÝ, K. (2005). Profiles Made by Powder Metallurgy Technology, Institute of materials and machine mechanics of the Slovak academy of sciences, Bratislava.

[6] POLETTI, P., BALOG, M., SIMANČÍK, F., DEGISHER, H. P. (2010). High temperature strength of compacted sub-micrometer aluminium powder, Acta materialia, Vol. 58, p. 3781.

[7] ASTM E 112 - 96, Standard Test Methods for Determining Avarage Grain Size, p. 227, 1996.

[8] VERLINDEN, B., FROYEN, L. (1994). Aluminium Powder Metallurgy, European Aluminium Association, p. 26.

[9] BALOG, M., SIMANČÍK, F., BAJANA, O., GUILLERMO, R. (2009). ECAP vs. direct extrusion - Techniques for consolidation of ultrafine Al particles, In: Materials science and engineering, A 504, 1-7.

[10]BALOG, M., SIMANČÍK, F., WALCHER, M., WALCHER, R., POLETTI, P. (2011). Extruded Al-Al $\mathrm{A}_{3}$ composites formrmed in situ during consolidation of ultrafine Al powders: Effect on the powder surface area, In: Materials science and engineering, A 529, 131-137

[11]SKLENIČKA, V., DVOŘÁK, SVOBODA, M. (2004). Creep in ultrafine grained aluminium, In: Materials science engineering, 2004, p. 387.

[12]CAVOJSKY, M., BAlOG, M., DVORAK, J., IllEKOVA, E., SVEC, P., KRIZIK, P., JANICKOVIC, D., SIMANCIK, F. (2012). Microstructure and properties of extruded rapidly sodified $\mathrm{AlCr}_{4,7} \mathrm{Fe}_{1,1} \mathrm{Si}_{0,3}($ at $\%$ ) alloys, In: Materials science engineering, A 549, 223-241. 